\title{
IMPATIENS SUBFALCATA (BALSAMINACEAE), A NEW SPECIES FROM LAOS
}

\author{
P. Souladeth ${ }^{1}$, S. Tagane ${ }^{2}$, Y. Suyama ${ }^{3}$, N. Ishii ${ }^{3}$, A. Nagahama $^{4} \&$ \\ K. Souvannakhoummane ${ }^{5}$
}

\begin{abstract}
Impatiens subfalcata Soulad. \& Tagane, a new species of Balsaminaceae from southern Laos, is described and illustrated. The new species is morphologically similar to Impatiens attopeuensis and I. notoptera in having succulent stems, serrate leaf margins and pinkish flowers, but distinguished from these two by its falcate lanceolate or oblanceolate leaves, more numerous secondary veins, shorter petioles and smaller dorsal petals.
\end{abstract}

Keywords. Balsaminaceae, Bolaven Plateau, Impatiens, Laos, new species, taxonomy. Received 17 June 2020 Accepted 13 November 2020 Published 07 April 2021

\section{Introduction}

Impatiens L. is a genus of Balsaminaceae comprising more than 1000 species. The genus is mainly distributed in tropical and subtropical Africa and Eurasia, with most species found in five hotspots, namely Southeast Asia and southwestern China, eastern to central Himalaya, southern India, tropical Africa, and Madagascar (Grey-Wilson, 1980, 1989; Chen et al., 2007; Cho et al., 2016; Ruchisansakun et al., 2018).

In Laos, thirty-five Impatiens species have been enumerated in the Flora of Laos (Newman et al., 2017-). The number of species reported is lower than that for neighbouring countries except Cambodia: more than 270 species (> 200 endemic) have been recorded from China (Chen et al., 2007; Lu et al., 2020), approximately 72 species from Vietnam (Tardieu, 1944; Ho, 2003; Shui et al., 2011; Botany Vietnam Group, continuously updated), 65 species from Myanmar (Kress et al., 2003; Ruchisansakun et al., 2018), 69 species from Thailand (Pooma \& Suddee, 2014; Ruchisansakun \& Suksathan, 2019), and nine species from Cambodia (Hooker, 1911; Tardieu, 1944; Cho et al., 2016, 2017; Kim et al., 2019).

During our recent floristic surveys on the Bolaven Plateau, southern Laos, in 2017-2019, a species of Impatiens belonging to section Uniflorae Hook.f. \& Thomson was collected

\footnotetext{
${ }^{1}$ Faculty of Forest Science, National University of Laos, Dongdok Campus, Xaythany District, Vientiane Capital, Laos. E-mail: p.souladeth@nuol.edu.la.

${ }^{2}$ Kagoshima University Museum, Kagoshima University, 1-21-30 Korimoto, Kagoshima 890-0065, Japan.

${ }^{3}$ Kawatabi Field Center, Graduate School of Agricultural Science, Tohoku University, 232-3 Yomogida, Naruko-onsen, Osaki, Miyagi 989-6711, Japan.

${ }^{4}$ Centre for Asian Conservation Ecology, Kyushu University, 744 Motooka, Fukuoka 819-0395, Japan.

${ }^{5}$ Centre for Development and Environment, Lao country office, Unit 11, \#136, Simuang Road, Hom 1, PO Box 1438, Ban Phapo, Vientiane, Laos.
} 
at Tad Seua Waterfall (Figure 1A). It is most similar to Impatiens attopeuensis Hook.f. from Attapeu Province of southern Laos, but a comparison with the type specimens and protologue of $I$. attopeuensis as well as those of the other species in Laos and surrounding countries revealed that it differs from any of the previously known species. Therefore, we describe it as a new species, Impatiens subfalcata Soulad. \& Tagane, the thirty-sixth Impatiens species from Laos. The measurements in the following description are based on the herbarium materials we collected.

\section{Taxonomic treatment}

Impatiens subfalcata Soulad. \& Tagane, sp. nov.

Impatiens subfalcata is easily recognised by its slightly falcate and lanceolate or oblanceolate leaves (length-to-width ratio, 4.6-7.6). In Laos, it is similar to Impatiens attopeuensis Hook.f. in its habit, serrate leaf margins and pinkish purple corolla, but distinguished not only by its slightly falcate leaves but also by its more numerous secondary veins (8-10 pairs in I. subfalcata versus $5-7$ pairs in I. attopeuensis), shorter petioles (subsessile to $0.2 \mathrm{~cm}$ long versus $0.5-2 \mathrm{~cm}$ long), shorter spur $(2.1-2.6 \mathrm{~cm}$ versus $4-7 \mathrm{~cm}$ long), and smaller dorsal petal (6-7 mm versus 12-14 mm). - Type: Laos, Champasak Province, Dong Hua Sao National Protected Area (Bolaven Plateau), $15^{\circ} 04^{\prime} 02.6^{\prime \prime} \mathrm{N}, 106^{\circ} 12^{\prime} 29.9^{\prime \prime E}, 1147$ m elevation, 19 ii 2019, Souladeth P., Tagane S., Sengthong A., Nagahama A., Suyama Y., Ishii N. L2492 (holotype FOF! [FOF0005191]; isotype BKF, HNL, KAG! [KAG128741]). Figure 1.

Lithophytic, perennial herb, $20-40 \mathrm{~cm}$ tall, stems upright, usually solitary, succulent, with slightly swollen, caudiform base, $0.4-1 \mathrm{~cm}$ in diameter at the base, light green, glabrous. Leaves alternate, spirally arranged, crowded towards apex of stems; petioles subsessile to $2 \mathrm{~mm}$ long, pale green, glabrous; lamina lanceolate, oblanceolate, slightly falcate, 1.7-10.5 $\times 0.2-1.7 \mathrm{~cm}$, length-to-width ratio $4.6-7.6$, thinly chartaceous, base cuneate to acute, slightly decurrent, apex acuminate, margin serrate, adaxially light grey-green, abaxially pale green, glabrous except upper adaxial side of secondary veins hairy, midrib prominent at base, flat, or slightly prominent or slightly sunken towards apex on both surfaces, secondary veins 8-10 pairs, clearly sunken abaxially, tertiary veins invisible on both surfaces. Flowers solitary, axillary, $1.3-1.5 \times 1.1-1.3 \mathrm{~cm}, 2.9-3.1 \mathrm{~cm}$ deep, purplish pink in vivo, pale blue-purple in sicco, with white at centre. Bracts narrowly ovate to triangular, c. $2 \mathrm{~mm}$ long, apex acute, light green, glabrous on both surfaces, persistent. Pedicel $1.2-2 \mathrm{~cm}$ long, $0.6-0.9 \mathrm{~mm}$ in diameter, light green, glabrous. Lateral sepals 2, ovate, triangular, c. $5 \times$ $2.8 \mathrm{~mm}$, apex acute to shortly acuminate, yellowish brown with green tips at apex, glabrous on both surfaces. Lower sepal navicular, 5-6 × 3-4 mm, c.1.5 mm deep, apex acute, white, glabrous, abruptly constricted distally into a straight or incurved spur, spur $2.1-2.6 \mathrm{~cm}$ long, white with green tip. Petals 5. Dorsal petal transversely broadly elliptic, $6-7 \times 7-9 \mathrm{~mm}$, 

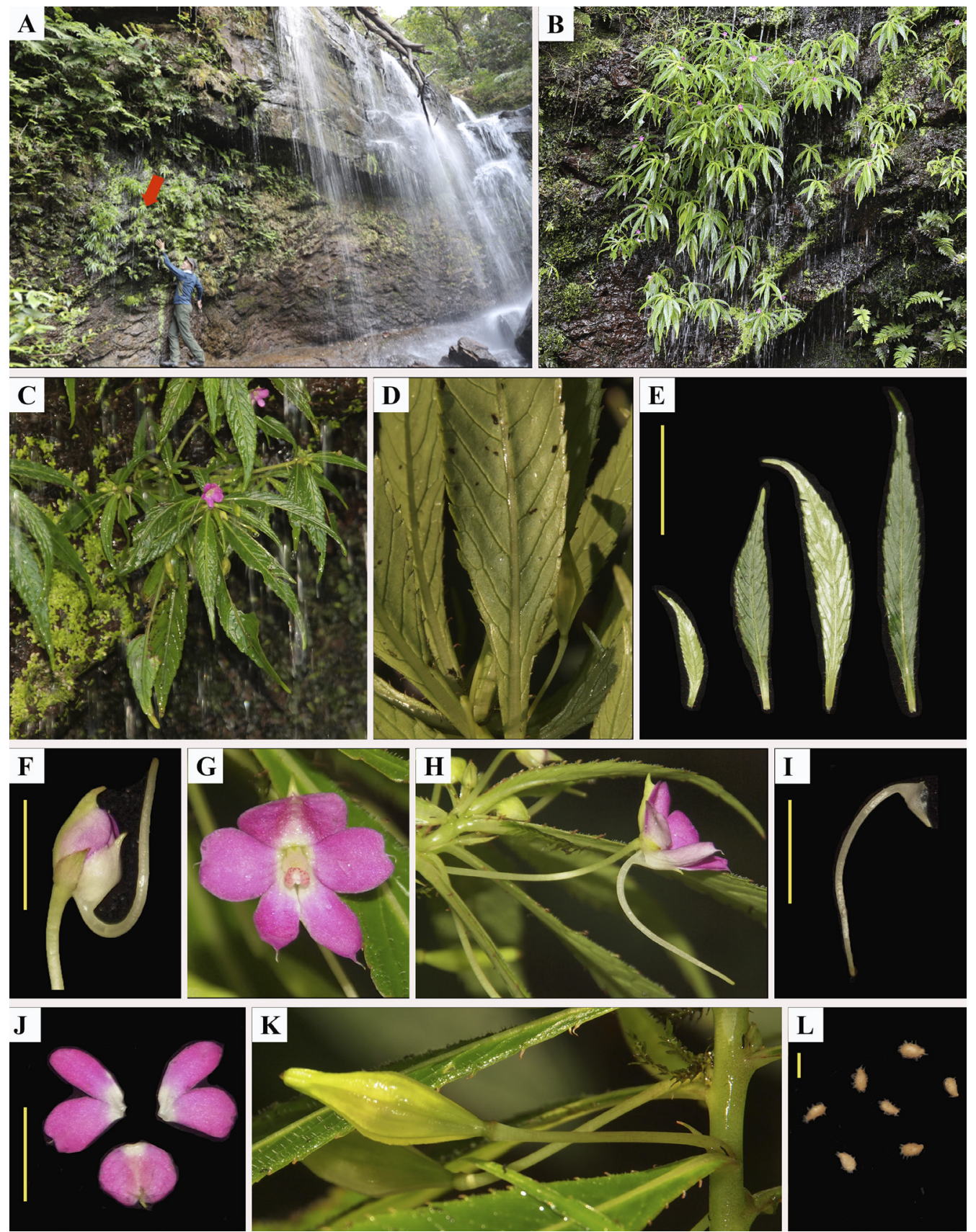

Figure 1. Impatiens subfalcata Soulad. \& Tagane. A and B, Habitat (individuals indicated by red arrow); C, habit; D, portion of lower leaf surface; E, leaves; F, flower bud; G, flower (front view); $H$, flower (lateral view); I, spur; J, petals; K, fruit; L, seeds. Scale bars (yellow): E, $5 \mathrm{~cm}$; F, I and J, $1 \mathrm{~cm}$; L, $2 \mathrm{~mm}$. All photographs from Souladeth et al. L2492. Photographs: S. Tagane. 
apically slightly recurved, apex obcordate and mucronate stipitate, mucro to $1.2 \mathrm{~mm}$ long, base truncate to rounded, purplish pink, except white near base, with green tip, glabrous on both surfaces. Lateral united petals broadly obovate, 9.5-12 mm long, free, purplish pink except white near base, glabrous on both surfaces; upper lobes obovate-elliptic, 11-12 $\times$ 4-4.5 $\mathrm{mm}$, apex round to slightly acuminate emarginate with appendage at apex, appendage 0.5-1.5 mm long, base cuneate; lower lobes obovate-elliptic, 9.5-11 × 5.2-6.1 mm, obovate-elliptic, apex slightly obcordate, with appendage at apex, appendage c. $1.2 \mathrm{~mm}$ long. Stamens 5, filaments c. $2.5 \mathrm{~mm}$ long, flat, pale pink, anthers pale pink. Ovary c. $2 \mathrm{~mm}$ long, c. $0.9 \mathrm{~mm}$ in diameter, 1 carpel, 4-lobed, green in vivo, reddish brown in sicco, glabrous. Fruits short, fusiform, 1.2-1.8 cm long, 5-6 mm in diameter, green in vivo, reddish brown in sicco, glabrous. Seeds c.20 per capsule, ellipsoid, 2-2.8 mm long, light brown, pilose.

Distribution. Laos, Champasak Province (known only from the type locality).

Habitat and ecology. Impatiens subfalcata grows on dripping rocky walls at a waterfall (see Figure 1A,B).

Etymology. The species epithet, subfalcata, is derived from the slightly falcate nature of the leaves of this species.

Vernacular name. ช๖นใบถาบ (thien baidab), suggested here; in Lao, thien means Impatiens species and baidab means 'falcate leaf'.

Preliminary conservation assessment. Impatiens subfalcata is currently known only from a single population with c.30 individuals at its type locality on the Bolaven Plateau (Figure 2) and may be restricted to dripping-wet, rocky walls. Therefore, the most appropriate initial assessment of the IUCN conservation status for this species is Critically Endangered (CR) under criteria D (IUCN, 2012).

Note 1 . The possibility that Impatiens subfalcata is simply an extreme variation of $I$. attopeuensis has been considered. Impatiens attopeuensis is a variable species, and two species, I. longecalcarata Tardieu and I. monotricha Hook.f., both described from Bolaven, are now treated as synonyms of $I$. attopeuensis in the checklist of Laos (Newman et al., 2017-). However, Impatiens subfalcata is different from these species not only in morphology (as shown in the diagnosis above and the Table) but also in its habitat and elevation range. Whereas Impatiens subfalcata grows on dripping rocky walls in wet evergreen forest at an elevation of $1147 \mathrm{~m}, \mathrm{l}$. attopeuensis, including the two synonymised species, grows on rocks or soils near streams or waterfalls at lower elevations, 199-900 m. The types of Impatiens attopeuensis (a drawing in Hooker's Icon. PI. 29: t. 2853; based on Harmand s.n., P), I. longecalcarata (Poilane 15955, P) and I. monotricha (Harmand 1137, P) were collected in Attapeu Province (at 600-900 m for I. longecalcarata and 200-300 m for I. monotricha).

We collected Impatiens attopeuensis at Tad Tayicseua Waterfall (Souladeth et al. L2573) at an elevation of $634 \mathrm{~m}$ (Figure 3) and at Tad Xe Ponglai Waterfall (Souladeth et al. L3222 

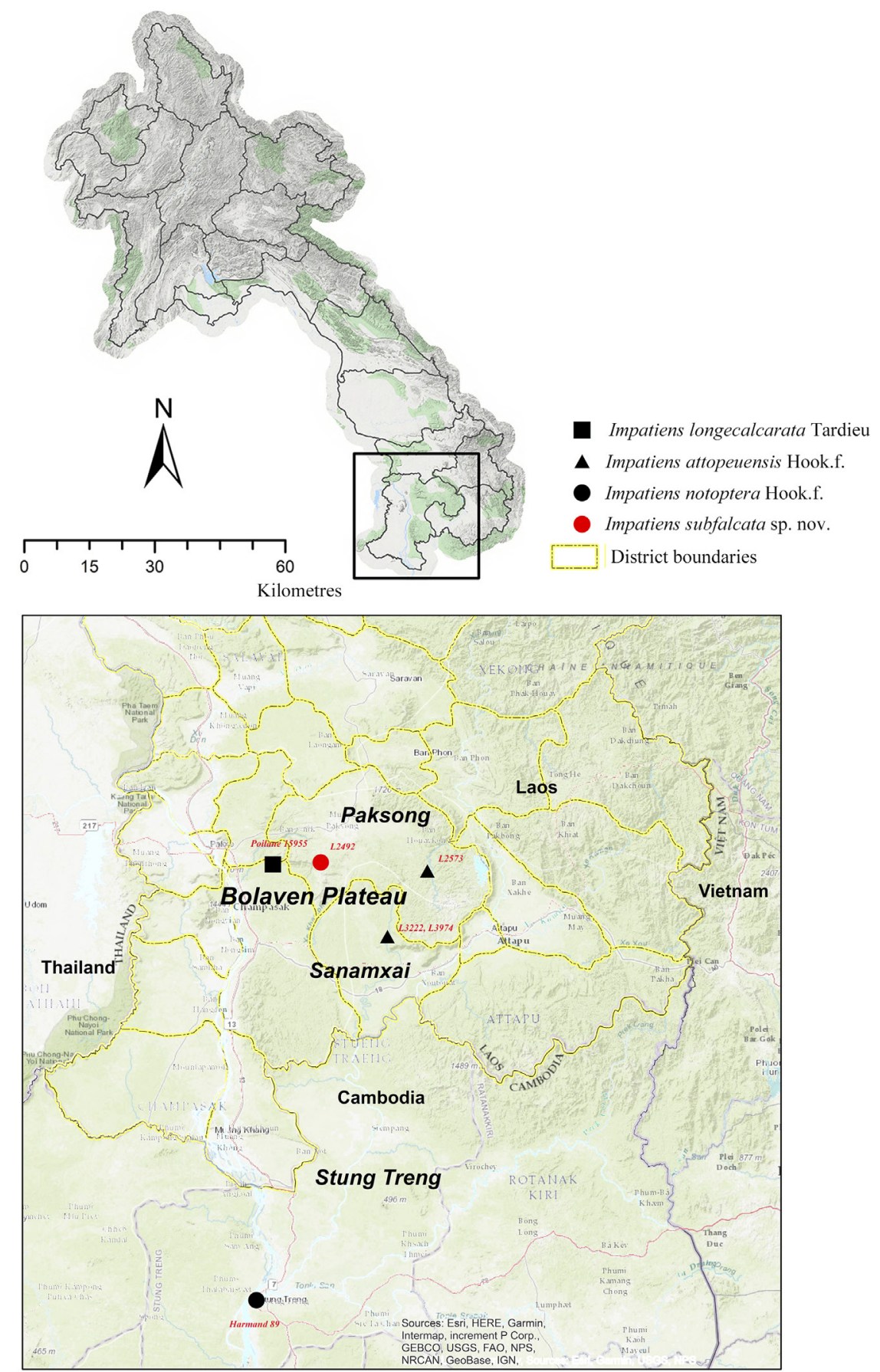

Figure 2. Distribution of Impatiens subfalcata and $I$. attopeuensis (including the type locality of I. longecalcarata and $I$. notoptera, both synonyms of $I$. attopeuensis) in Laos and Cambodia. 

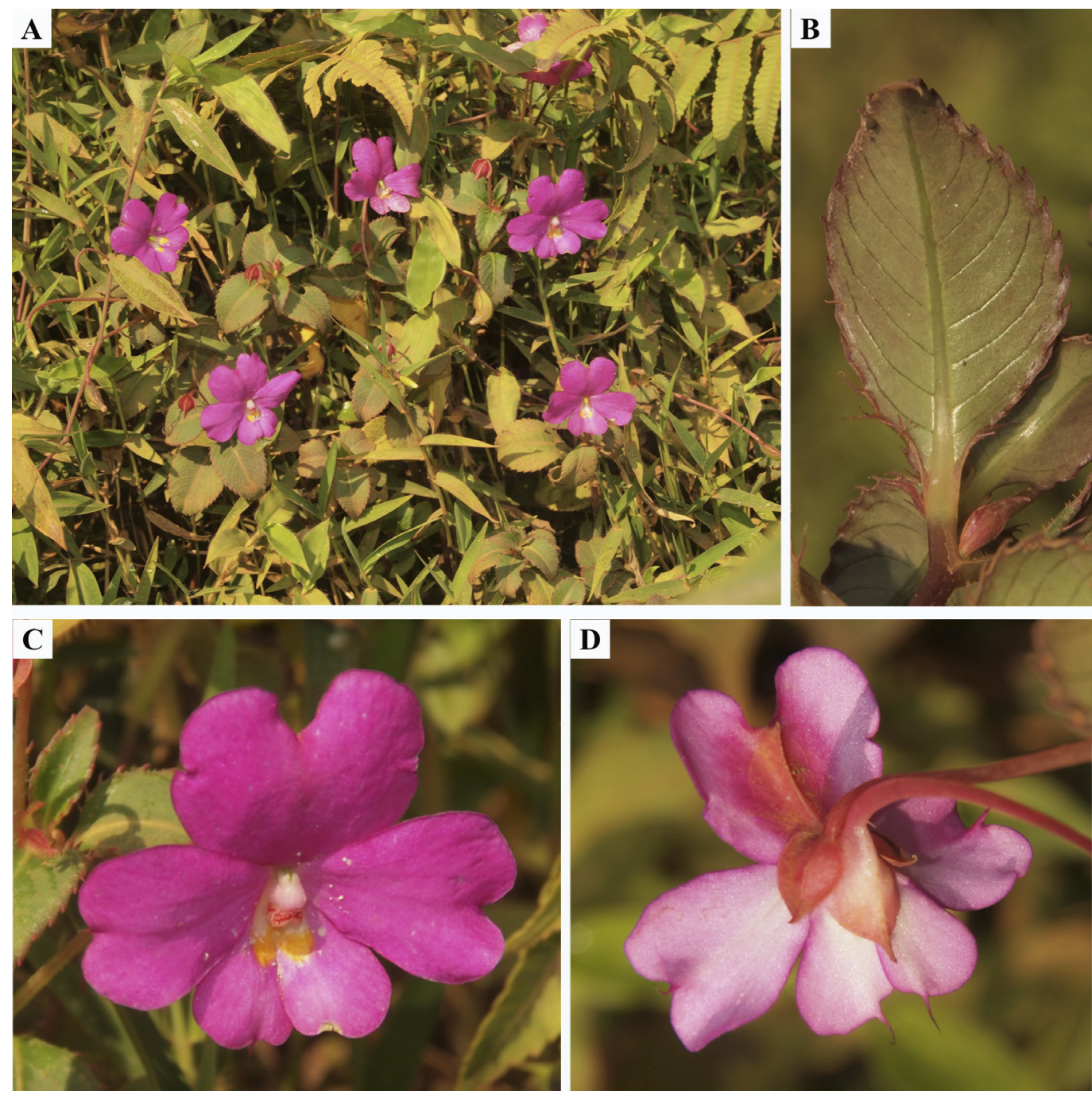

Figure 3. Impatiens attopeuensis at Tad Tayicseua Waterfall, at elevation $634 \mathrm{~m}$, Champasak Province. A, Habit; B, lower leaf surface; C, flower (front view): D, flower (lateral view). All photographs from Souladeth et al. L2573. Photographs: S. Tagane.

and Souladeth et al. L3974) at $199 \mathrm{~m}$ (Figure 4). These collections are deposited in FOF and KAG. We conducted wide-ranging surveys in the four provinces of Attapeu, Champasak, Salavan and Sekong on the Bolaven Plateau in December 2018, February, July and December 2019, and September 2020, and never encountered Impatiens attopeuensis above $1000 \mathrm{~m}$ elevation or observed any morphological intermediates between the two species. Given this, we consider that Impatiens subfalcata is a distinct species. Because Impatiens subfalcata 

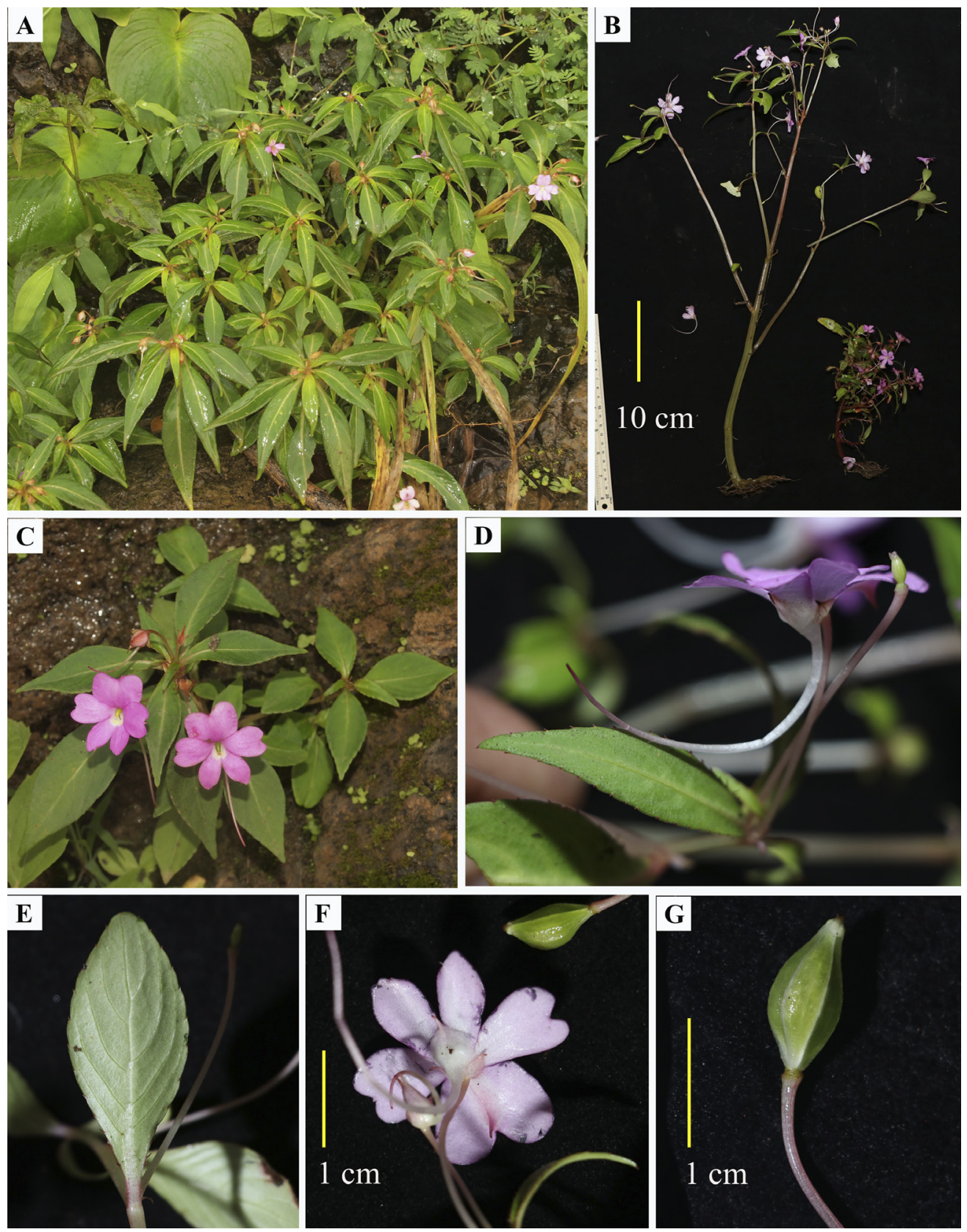

Figure 4. Impatiens attopeuensis (form corresponding to I. longecalcarata) at Tad Xe Ponglai Waterfall, at elevation 199 m, Attapeu Province. A and B, Habit; C, individual and flowers (front view); D, flower and leaf (lateral views); E, lower leaf surface; F, flower (back view); G, fruit. A and C from Souladeth et al. L3222; B and D-G from Souladeth et al. L3974. Photographs: A and C, S. Tagane; B and D-G, K. Souvannakhoummane. 
is morphologically most similar to $I$. attopeuensis, it may have recently originated from it. Further phylogenetic analysis will help to clarify the relationship between these two species.

Note 2. Impatiens subfalcata is also similar to I. notoptera Hook.f. (sometimes treated as a synonym of $I$. semounensis Hook.f.), known from Stung Treng, Cambodia, but can be distinguished by its narrower leaf blades (length-to-width ratio 4.6-7.6 in I. subfalcata versus 1.8-2.4 in I. notoptera), shorter petiole (subsessile to $0.2 \mathrm{~cm}$ long versus $2-4 \mathrm{~cm}$ long), and larger lateral petals (10-12 $\mathrm{mm}$ long versus c. $6 \mathrm{~mm}$ long).

Note 3. The recent infrageneric classification of Impatiens by Yu et al. (2016) divided the genus into two subgenera (subg. Clavicarpa S.X.Yu ex S.X.Yu \& Wei Wang and subg. Impatiens), and further divided subgenus Impatiens into seven sections (sect. Fasciculatae X.S.Yu \& Wei Wang, sect. Impatiens, sect. Racemosae Hook.f. et Thomson, sect. Scorpioidae S.X.Yu \& Wei Wang, sect. Semeiocardium (Zoll.) S.X.Yu \& Wei Wang, sect. Tuberosae S.X.Yu \& Wei Wang and sect. Uniflorae Hook.f. \& Thomson). Impatiens subfalcata belongs to section Uniflorae by its fusiform capsule, conspicuously turgid at the middle, many ovules per locule, and ellipsoid seeds.

The Table summarizes the morphological differences between Impatiens subfalcata, I. attopeuensis and I. notoptera.

Table. Morphological comparison between Impatiens subfalcata, I. attopeuensis and I. notoptera

\begin{tabular}{|c|c|c|c|}
\hline Character & I. subfalcata & I. attopeuensis ${ }^{\mathrm{a}}$ & I. notoptera ${ }^{\mathrm{a}}$ \\
\hline Lamina shape & $\begin{array}{l}\text { Lanceolate, oblanceolate, } \\
\text { slightly falcate }\end{array}$ & $\begin{array}{l}\text { Ovate to ovate-lanceolate, } \\
\text { symmetrical }\end{array}$ & Ovate, symmetrical \\
\hline Lamina length & $1.7-10.5 \mathrm{~cm}$ & $3-5 \mathrm{~cm}$ & $4-6 \mathrm{~cm}$ \\
\hline $\begin{array}{l}\text { Length-to-width } \\
\text { ratio of lamina }\end{array}$ & $4.6-7.6$ & $2.1-2.8$ & $1.8-2.4$ \\
\hline $\begin{array}{l}\text { No. of secondary } \\
\text { veins }\end{array}$ & 8-10 pairs & $5-6(-7)$ pairs & 6-8 pairs \\
\hline Petiole length & Subsessile to $0.2 \mathrm{~cm}$ & $0.5-2 \mathrm{~cm}$ & $2-4 \mathrm{~cm}$ \\
\hline Lateral sepals & $\begin{array}{l}2 \text {, ovate-triangular, } 5 \times \\
2.8 \mathrm{~mm} \text {, acute to shortly } \\
\text { acuminate at apex }\end{array}$ & $\begin{array}{l}\text { 2, ovate-circular, } 7 \times 7 \mathrm{~mm} \text {, } \\
\text { acute at apex }\end{array}$ & $\begin{array}{l}\text { 2, ovate-circular, c. } 5 \times 3 \mathrm{~mm} \text {, } \\
\text { cuspidate at apex }\end{array}$ \\
\hline Lower sepal & Navicular, 5-5.5 mm long & Navicular, $12 \mathrm{~mm}$ long & Navicular, $4 \mathrm{~mm}$ long \\
\hline Spur length & $2.1-2.6 \mathrm{~cm}$ & $4-7 \mathrm{~cm}$ & $2-2.5 \mathrm{~cm}$ \\
\hline Dorsal petal & $\begin{array}{l}\text { Transversely broadly elliptic, } \\
6-7 \mathrm{~mm} \text { long }\end{array}$ & $\begin{array}{l}\text { Broadly obovate, } 12-14 \mathrm{~mm} \\
\text { long }\end{array}$ & $\begin{array}{l}\text { Broadly obovate-circular, } \\
\text { c. } 8 \mathrm{~mm} \text { long }\end{array}$ \\
\hline Lateral petals & $\begin{array}{l}\text { United, broadly obovate, } \\
10-12 \mathrm{~mm} \text { long }\end{array}$ & $\begin{array}{l}\text { United, broadly obovate, } \\
5 \mathrm{~mm} \text { long }\end{array}$ & $\begin{array}{l}\text { United, broadly obovate, } \\
\text { c. } 6 \mathrm{~mm} \text { long }\end{array}$ \\
\hline Seeds & $\begin{array}{l}\text { Ellipsoid, 2-2.8 mm long, } \\
\text { pilose }\end{array}$ & $\begin{array}{l}\text { Ellipsoid, c. } 2.2 \mathrm{~mm} \text { long, } \\
\text { short hairy }\end{array}$ & $\begin{array}{l}\text { Oblong to obovoid, c. } 3 \mathrm{~mm} \text {, } \\
\text { glabrous, granulate }\end{array}$ \\
\hline
\end{tabular}

a The measurements of Impatiens attopeuensis and $I$. notoptera are based on the published protologues (Hooker, 1908 and 1909, respectively), digitised herbarium specimens available on the web (e.g. JSTOR Global Plants, continuously updated), and our specimens of $I$. attopeuensis (i.e. Souladeth et al. L2573, L3222 and L3974 [FOF, KAG]). 


\section{Acknowledgements}

The authors are grateful to the managers and staff of Dong Hua Sao National Protected Area for their assistance in the field. We also thank the curators of FOF, FU, HNL and KAG for making their specimens accessible, and Sangmany Boutthavong (Faculty of Forest Science, National University of Laos) for providing a map. This study was supported by the Nagao Natural Environment Foundation, Japan.

\section{References}

Botany Vietnam Group. Continuously updated. Vietnam Plant Data Center. Online database. http://www. botanyvn.com/ [Accessed 8 June 2020.]

Chen Y-L, Akiyama S, Ohba H. 2007. Balsaminaceae. In: Wu ZY, Raven PH, Hong D-Y, editors. Flora of China, Volume 12 (Hippocastanaceae through Theaceae). Beijing: Science Press, and St Louis: Missouri Botanical Garden Press. pp. 43-113.

Cho SH, Chhang P, Kim Y-D. 2016. A Checklist for the Seed Plants of Cambodia. Incheon: National Institution of Biological Resources, Ministry of Environment. $272 \mathrm{pp}$.

Cho S-H, Kim B-Y, Park H-S, Chhang P, Kim Y-D. 2017. Impatiens bokorensis (Balsaminaceae), a new species from Cambodia. PhytoKeys. 77:33-39.

Grey-Wilson C. 1980. Impatiens of Africa: Morphology, Pollination and Pollinators, Ecology, Phytogeography, Hybridisation, Keys and a Systematic Treatment of All African Species with a Note on Collecting and Cultivation. Rotterdam: Balkema.

Grey-Wilson C. 1989. A revision of Sumatran Impatiens: Studies in Balsaminaceae: VIII. Kew Bulletin. 44(1):67-106.

Ho PH. 2003. Balsaminaceae. In: An Illustrated Flora of Vietnam, vol. 2. Ho Chi Minh City: published by author. $951 \mathrm{pp}$.

Hooker JD. 1908. Impatiens attopeuensis Hook.f. Hooker's Icones Plantarum, vol. 29: t. 2853.

Hooker JD. 1909. Impatiens d'Indo-Chine. In: Lecomte H, editor. Notulae Systematicae. Paris: Masson. pp. 10-14.

Hooker JD. 1911. Balsaminacees. In: Lecomte H, Gagnepain F, editors. Flore Générale de l'Indo-Chine, vol. 1. Paris: Masson. pp. 611-629.

IUCN. 2012. IUCN Red List Categories and Criteria, version 3.1. IUCN Species Survival Commission. Gland, Switzerland, and Cambridge: International Union for Conservation of Nature.

JSTOR Global Plants. Continuously updated. Electronic database. https://plants.jstor.org/

Kim B-Y, Won H, Chhang P, Lim C-K, Shin J-S, Kim Y-S, Cho S-H. 2019. Impatiens cardamomensis (Balsaminaceae), a new species from Cambodia. Korean Journal of Plant Taxonomy. 49(4):319-323.

Kress WJ, DeFilipps RA, Farr E, Kyi DYY. 2003. A Checklist of the Trees, Shrubs, Herbs, and Climbers of Myanmar (Revised from the Original Works by J. H. Lace, R. Rodger, H. G. Hundley, and U Chit Ko Ko on the "List of Trees, Shrubs, Herbs and Principal Climbers, etc. Recorded from Burma". Contributions from the United States National Herbarium. 45:1-590. 
Lu Z-C, Pan B, Huang F-Z, Liu Y. 2020. Impatiens gongchengensis (Balsaminaceae), a new species from Guangxi, Southern China. Taiwania. 65(1):1-4.

Newman MF, Pullan M, Ketphanh S, Svengsuksa B, Thomas P, Sengdala K, Lamxay V, Armstrong K. 2017-. A Checklist of the Vascular Plants of Lao PDR. Online database. https://padme.rbge.org.uk/ laos/ [Accessed 8 June 2020.]

Pooma R, Suddee S, editors. 2014. Tem Smitinand's Thai Plant Names, revised edition. Bangkok: The Office of the Forest Herbarium, Department of National Parks, Wildlife and Plant Conservation.

Ruchisansakun S, Suksathan P. 2019. Impatiens jenjittikuliae (Balsaminaceae), a new species from Thailand. PhytoKeys. 124:139-147.

Ruchisansakun S, Suksathan P, Van der Niet T, Smets EF, Lwin S, Janssens SB. 2018. Balsaminaceae of Myanmar. Blumea. 63(3):199-267.

Shui Y-M, Janssens S, Huang S-H, Chen W-H, Yang Z-G. 2011. Three new species of Impatiens L. from China and Vietnam: preparation of flowers and morphology of pollen and seeds. Systematic Botany. 36(2):428-439.

Tardieu BM. 1944. Les Impatiens d'indochine, répartition, affinités et description d'espèces nouvelles. Notulae Systematicae, Herbier du Muséum de Paris. 11:169-185.

Yu S-X, Janssens SB, Zhu X-Y, Lidén M, Gao T-G, Wang W. 2014. Phylogeny of Impatiens (Balsaminaceae): integrating molecular and morphological evidence into a new classification. Cladistics. 32(2):179-197. 